\title{
Police officers' views of effective interview tactics: The effects of weight of case evidence and discomfort with ambiguity
}

\begin{tabular}{|r|l|}
\hline Journal: & Applied Cognitive Psychology \\
\hline Manuscript ID: & ACP-07-0090.R2 \\
\hline Wiley - Manuscript type: & Research Article \\
\hline Author: Submitted by the \\
Authomplete List of Authors: & $\begin{array}{l}\text { Häkkänen, Helinä; National Bureau of Investigation, Criminal } \\
\text { Intelligence Division; University of Helsinki, Psychology } \\
\text { Ask, Karl; Göteborg University, Department of Psychology } \\
\text { Kebbell, Mark; Griffith University, Psychology } \\
\text { Alison, Laurence; The University of Liverpool, Psychology } \\
\text { Granhag, Pär Anders; Göteborg University, Department of } \\
\text { Psychology }\end{array}$ \\
\hline Keywords: & $\begin{array}{l}\text { Police interview, Weight of evidence, Discomfort with ambiguity, } \\
\text { Suspect Interview, Need for Closure }\end{array}$ \\
\hline
\end{tabular}

\section{(5)holarONE" \\ Manuscript Central}


Police officers' views of

\section{Running head: POLICE OFFICERS' VIEWS OF}

Police officers' views of effective interview tactics with suspects:

The effects of weight of case evidence and discomfort with ambiguity

Helinä Häkkänen ${ }^{\mathrm{a}, \mathrm{b}}, \operatorname{Karl~Ask}^{\mathrm{c}}$, Mark Kebbell ${ }^{\mathrm{d}}$, Laurence Alison ${ }^{\mathrm{e}} \&$ Pär Anders Granhag ${ }^{\mathrm{c}}$

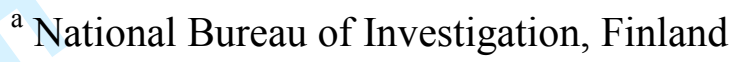

${ }^{\mathrm{b}}$ Department of Psychology, University of Helsinki, Finland

${ }^{\mathrm{c}}$ Department of Psychology, Göteborg University, Sweden

${ }^{\mathrm{d}}$ School of Psychology, Griffith University, Australia

${ }^{\mathrm{e}}$ School of Psychology, University of Liverpool, UK

Correspondence should be addressed to:

Helinä Häkkänen

National Bureau of Investigation

P.O.Box 285

FIN-01301

Vantaa, Finland

Tel. +358983886580

fax. +358983886496

e-mail: helina.hakkanen@krp.poliisi.fi 
Police officers' views of

\begin{abstract}
This study examined the effects of case-specific facts and individual discomfort with ambiguity on investigators' beliefs concerning effective interviewing tactics for suspects. Violent crime investigators $(n=30)$ responded to a questionnaire including the Need for Closure Scale and ratings of the importance of 39 interrogation tactics in two hypothetical interrogations with a homicide suspect, where the evidence consisted of either technical evidence or soft information. Twenty tactics were analysed with a multidimensional scaling procedure which confirmed two discrete interviewing themes: humane and dominant. More tactics, both dominant and humane, were rated as important if the evidence was soft compared with technical. In the soft evidence condition, investigators who were high on discomfort of ambiguity (DA) rated both types of tactics as more important than did low-DA investigators. In the technical evidence condition, no such difference emerged.

Key words: Police Interview; Suspect Interview, Weight of Evidence, Discomfort with Ambiguity, Need for Closure
\end{abstract}


Police officers' views of

The aim of the suspect interview is to obtain valid and reliable information in order to provide the prosecutor and the judge or jury with a coherent account of the crime (Memon, Vrij, \& Bull, 2003). Much research attention has been paid to police interview styles (e.g. Baldwin, 1992; Bull, 1999; Cherryman, \& Bull, 2000, 2001; Holmberg, 2004; Jones, MacLean \& Young, 1986; Milne \& Bull, 1999; Moston, 1996; Moston et al., 1992; Moston \& Engelbern, 1993; Moston \& Stephenson, 1993; Smith, 1983; Williamson, 1993; Vrij, 2003) and many scholars have raised doubts about the ethics of police interview (Baldwin, 1993; Gudjonsson, 2003; Huff, Rattner, \& Sagarin, 1996; Pearse \& Gudjonsson, 1999). Furthermore, in the recent decades, a number of miscarriages of justice connected to the interview situation have resulted in legal regulations as to what can and cannot be done in a suspect interview (e.g., the PACE Act in the UK). However, these rules are typically general and prohibit only the most extreme strategies for unethical interviewing. Hence, the use of some more subtly manipulative tactics, as opposed to more sensitive and attentive methods, is left to the individual interviewer's discretion.

At the same time, several authors have criticised police interviews for adopting too narrow a focus. For example, some authors have argued that investigators too often do not challenge the denying suspect, and tend to stick to only one strategy, even if it does not work (Baldwin, 1993; Moston et al., 1992; Pearse \& Gudjonsson, 1996; Stephenson \& Moston, 1994). This calls for research on the determinants of interview styles. For instance, it may be that interviewers prefer different approaches depending on the characteristics of the case. Furthermore, individual differences in interviewers' personality may contribute to different preferences for particular tactics. In this paper we examine how the strength of evidence and interviewers' discomfort with ambiguity influence the perceived importance of different interview tactics. 
Police officers' views of

An investigator is often faced with a wide range of information when planning and conducting a suspect interview, such as statements from witnesses and victims, technical evidence (e.g., DNA, fingerprints), information regarding the arrest and custody, and "soft" information (e.g., rumours, tips from informers). Different types of information and evidence have been found to have different impact on investigative judgments (Ask, Rebelius, \& Granhag, 2008), and the style of interviewing is likely to be affected by these factors as well. For example, suspect reluctance is likely to affect the interview style, thus leading to more persuasive and occasionally unprofessional interview tactics (Evans, 1993; Leo, 1992, 1996; McConville \& Hodgson, 1993; Moston \& Engelberg, 1993; Pearse \& Gudjonsson, 1999; Stephenson \& Moston, 1994). Also, the investigator's presumptions about the case or the suspect may lead to 'confirmation bias' and influence his/her way of interviewing (Hargie \& Tourish, 1999; Mortimer \& Shephard, 1999). For example, a person's previous conviction is likely to increase the investigator's belief in the suspect's guilt (Firth, 1995; Moston \& Stephenson, 1993), and may lead to him/her putting greater emphasis on obtaining a confession by using an accusatory interviewing style (Mortimer, 1994; Moston \& Stephenson, 1993; Stephenson \& Moston, 1994). Kassin, Goldstein and Savitsky (2003) showed that interrogators who presumed that a mock suspect was guilty used a more aggressive interview style, thus selecting more guilt-presumptive questions and exerting more pressure to get a confession.

Offence seriousness is also likely to influence interview style. Moston et al. (1992) found that an information-gathering (vs. accusatory) style was more frequent in sex-related crimes. However, in a survey by Holmberg and Christiansson (2002) sexual offenders, compared to homicide offenders, reported a higher degree of coercive style in their own police interviews. Nevertheless, it remains unclear to what degree this was influenced, for example, by there being less evidence against sexual offenders, by the suspect's behaviour, and by the interviewer's personality. 
Police officers' views of

One relatively under-researched topic is the interplay between an investigator's motivational state and his or her interview style. A large body of social-psychological research makes a convincing case that individuals' style of interaction and social judgment varies as a function of their current motivation (for reviews, see Kruglanski, 1996; Kunda, 1990). Hence, an officer's goals and motives with regard to an investigation or an interview may prove a likely determinant of the interaction and judgments occurring in the interrogation room. Although investigators' motivations have been the focus of previous studies (Ask \& Granhag, 2005, 2007), to our knowledge, this has rarely been studied within the context of suspect interviews, other than in the preliminary hints about the relationship between cognitive closure and the preference for more coercive thematic styles (Alison, Kebbell \& Leung, 2008).

In line with the previous research of Ask \& Granhag $(2005,2007)$, we argue that the need for closure (NFC; Kruglanski \& Webster, 1996) is of particular relevance to the investigative context. As originally defined by Kruglanski (1989), NFC refers to "the desire for a definite answer on some topic, any answer as opposed to confusion and ambiguity" (p. 14). This desire arises whenever ambiguity and uncertainty concerning a judgmental topic is perceived as unpleasant and/or costly, for instance when occupied with a boring or unattractive task (Mayseless \& Kruglanski, 1987; Webster, 1993), under time pressure (Kruglanski \& Freund, 1983), in the presence of environmental distraction (e.g., Kruglanski \& Webster, 1991; Kruglanski, Webster, \& Klem, 1993), or when mentally fatigued (Webster Nelson, Klein, \& Irvin, 2003; Webster, Richter, \& Kruglanski, 1996). The time pressure present in many criminal investigations (Greenwood, Petersilia, \& Chaiken, 1977; Innes, 2003), and the general normative pressure on investigators to "get results" (Mortimer \& Shepherd, 1999), is likely to create a heightened level of NFC. Consistent with this assumption, Ask and Granhag (2007) found that time pressure induced in an experimental setting did increase investigators' motivation to reach firm conclusions during an investigation. The motivation to seek closure 
Police officers' views of

also varies between individuals as a trait that generalizes across situations (Webster \& Kruglanski, 1994). Thus, the level of activation of closure goals appears to be chronically higher in some people than in others. Webster and Kruglanski (1994) demonstrated that this disposition can be measured by the Need for Closure Scale (NFCS), which today is widely used in social psychological research (e.g., Anseel \& Lievens, in press; Kosic, Kruglanski, Pierro, \& Mannetti, 2004).

Previous non-applied research has demonstrated that NFC may substantially affect the mental processes of the social perceiver. Generally speaking, a heightened NFC gives rise to two distinct tendencies; the 'urgency' tendency and the 'permanence' tendency (Kruglanski \& Webster, 1996). The former refers to the inclination to base one's judgments and decisions on early as opposed to late information, whereas the latter labels the tendency to preserve one's initial judgments and decisions in light of new information. In terms of practical consequences, a heightened NFC has been shown to exacerbate impressional primacy effects (i.e., basing judgments of other people on information received early; Webster et al., 1996), the fundamental attribution error (i.e., overestimating trait characteristics and underestimating situational factors as causes of behavior; Webster, 1993), and the resistance to persuasion in the presence of a prior opinion (Kruglanski et al., 1993).

In the vast majority of previous survey research, police officers' perceptions of effective interview tactics have been examined per se (e.g. Cherryman \& Bull, 1999; Soukara, Bull, \& Vrij, 2002; Williamson, 1993). To our knowledge only one study has looked at the influence of personality on self-reported use of different interview tactics (Alison et al, 2008). Alison et al. surveyed 99 police interviewers from the Crime Wing Headquarters of the Hong Kong Police. They found that high scorers on the discomfort with ambiguity subscale of the NFCS were more willing to use a variety of tactics (including more coercive cognitive and emotional tactics) than low scorers. However, to date there are no studies that have investigated the 
Police officers' views of

possible effects of the case details and the personality of the interviewer. This is an important point because in previous field studies (e.g. Baldwin, 1992, 1993; Holmberg, 2004; Moston et al., 1992; Moston \& Engelbern, 1993; Pearse and Gudjonsson, 1996, 1999; Williamson, 1993) several contextual factors are very likely to have influenced the interview style adopted (e.g. suspect response, interviewer personality or the weight of evidence).

In line with Alison et al (2008) and Holmberg \& Christianson (2002) the present study sought to establish whether interview tactics can be represented by two interacting facets (humane and dominant). Furthermore, the present study sought to identify investigators' perceptions of interview tactics in the context of a particular case, and in the presence of different types of evidence. Specifically, police officers were asked to consider the importance of various tactics in two hypothetical interrogations with a homicide suspect, where the evidence consisted of either technical evidence or "soft" information (i.e., a reliable hint from a third person). To our knowledge there is very little empirical research on the relationship between different types of evidence and the preference for different interview tactics, although a general hypothesis of the possible association has been explicated (Hartwig, Granhag \& Vrij, 2005). In their study on the effects of weight of evidence on suspect behaviour, Moston et al. (1992) however discuss that the choice of interview style seemed to be related to the weight of evidence, although this was not directly measured. Based on Moston et al's (1992) study, the current paper hypothesises that the strength of the evidence would have an effect on investigators' perception of the importance of different interview tactics. Specifically, we hypothesised that investigators would rate both humane (e.g. expressing empathy and positive attitude) and dominant tactics (e.g. being aggressive, brusque and impatient, Holmberg \& Christianson, 2002) as more important in the soft evidence condition because their need for information in this case is larger than if there is technical (such as DNA) evidence suggesting 
Police officers' views of

the suspect's guilt. Thus, compared to technical evidence condition, in soft evidence condition there would be a higher preference for any tactic that may elicit information.

In a second hypothesis, we predicted that in line with Alison et al (2008) there would be an influence of the investigators' level of need for closure on the perception of important tactics. However, rather than delineating a simple, uniform effect of NFC, we believe that the nature of the influence would depend on the available evidence in the case. Also, we chose to focus on the discomfort with ambiguity (DA) subscale of the NFC concept, arguing that the use of interview tactics is likely to relate particularly to interrogators' orientation towards ambiguity, rather than to other subscales such as decisiveness or the need for predictability. When an investigator enters the interrogation with weak evidence (i.e., soft information) there is a certain amount of ambiguity. By definition, this ambiguity should be perceived as less desirable by investigators high, as compared to low, in DA. The most apparent means to eliminate ambiguity in an interview is to actively elicit information relevant to the question of guilt. Hence, in the presence of only soft information, we predicted that investigators high in DA would consider the use of interview tactics overall to be more important than investigators low in DA. In contrast, when there is strong technical evidence, the investigator faces comparatively little ambiguity, and new information is of limited value to further disambiguate the situation. Arguably, the absence of ambiguity makes individual differences in discomfort with ambiguity less influential. Thus, in the presence of technical evidence, we predicted that there would be no differences between interviewers high and low in DA.

\section{Methods}

Participants

\footnotetext{
${ }^{*}$ This is in line with a recommendation by Neuberg, Judice \& West (1997) not to use the Need for Closure Scale as a unidimensional instrument, as it may mask potentially interesting and important findings from the subfacet level.
} 
Police officers' views of

Twenty one violent crime investigators who were participating on an in-service, advanced training course on violent crime (provided by the Police School) were asked to participate in the survey and fill in the questionnaire during the course. All of them did so. Also, 13 investigators from a violent crime unit were asked to participate in the survey. Nine of them responded. In both groups, the questionnaire was completed anonymously and returned directly to the first author.

The total sample in this study thus consisted of 30 violent crime investigators (13 male and 17 female), whose mean age was 38.63 years $(\mathrm{SD}=6.90$, range $28-52)$, and whose average length of police service was 13.38 years $(\mathrm{SD}=8.91$, range $1-30)$. The average length of violent crime investigation within the police was 7.23 years $(\mathrm{SD}=6.27)$. Thus, the participants were very experienced investigators who have extensive experience of interviewing in violent crime. Seven participants had however never been involved in a homicide investigation (all of them were specialised in sexual crimes). The average number of homicide investigations conducted by the remaining participants was 13.87 ( $\mathrm{SD}=22.44)$. Fifteen participants had never interviewed a homicide suspect. Among the remaining participants, the average number of homicide suspect interviews was $24.47(\mathrm{SD}=39.73)$.

\section{Questionnaire}

A questionnaire was designed to obtain some biographical data and the perceived importance of different interview tactics. The tactics were drawn from the literature and books regarding police interview (e.g. Baldwin, 1992; Cherryman, \& Bull, 2001; Holmberg, 2004; Pearse \& Gudjonsson, 1999), The list of tactics was further discussed with two experienced homicide investigators in order to ensure that no relevant tactics would be missing from the list. The questionnaire presented the respondents with the tactics and skills listed in Table 1. Respondents were asked to rate how important they considered each of these tactics when interviewing a homicide suspect in two different hypothetical scenarios, using a 4-point Likert 
Police officers' views of

scale $(1=$ not at all important, $4=$ very important $)$. The first scenario given to participants involved technical evidence against the suspect, but no soft evidence. The second scenario given to participants involved no technical evidence but soft evidence suggesting the suspect's guilt. The wording in both scenarios was identical (stating "Please rate the importance of each tactic when you are interviewing a homicide suspect in a case including no technical evidence but a reliable hint from a third person suggesting the suspect's guilt" vs. "Please rate the importance of each tactic when you are interviewing a homicide suspect in a case including technical evidence [the suspect's DNA at the scene and fingerprints on the murder weapon] but no soft evidence, e.g. hints). The clarity and unambiguity of the scenarios was ascertained by a discussion with the two experienced homicide investigators. The order of the scenarios was randomized across subjects.

For the purposes of the study, the Need for Closure Scale (NFCS; Webster \& Kruglanski, 1994) was translated into Finnish by a licensed Finnish translator. The scale consists of 42 statements, some of which reflect a tendency to seek closure (e.g. 'I don't like situations that are uncertain', 'I usually make important decisions quickly and confidently'), and some of which indicate an avoidance of closure (e.g. 'Even after I've made up my mind about something, I am always eager to consider a different opinion', 'I tend to put off making important decisions until the last possible moment'). The scale includes five subscales and one of these — discomfort with ambiguity—was of particular interest in the present study. After completing the interrogation tactics section of the questionnaire, the respondents filled in the NFCS.

In order to test the hypotheses, twenty tactics that we considered undoubtedly 'dominant' or 'humane' based on the definitions of Holmberg and Christianson (2002) were selected. The dominant tactics relate to lack of calmness, hostility, persistency, and condemning attitudes while the humane tactics relate to sensitiveness, cooperation, and lack of 
Police officers' views of

presumptions. Smallest Space Analysis (SSA) was used to test this conceptualisation of the thematic structure of the suspect interviewing tactics (Shye, 1994).

\section{Results}

Table 1 displays the distribution of responses as well as means and standard deviations for each skill and tactic. It shows that 'thorough knowledge of case' was considered as the most important in both conditions, with over $80 \%$ of the respondents considering it to be 'very important'. 'Judgemental attitude' received the lowest rating for importance, with over $90 \%$ of the respondents considering it 'not at all important'.

Insert Table 1 about here

\section{Categorisation of Interview Tactics}

The visual representation of the SSA correlations between the twenty selected tactics is shown in Figure 1. Each tactic is more fully defined in Table 2. SSA represents the correlations between variables as distances in a conceptual space, using the rank order relationships between each and every variable. The closer two variables are, the higher their rank ordered relationship with one another. The accuracy of the fit of the visual representation to the metric relationships is measured by the coefficient of alienation $(\mathrm{CoA})$, In this case the CoA is 0.14 , which is considered a good fit (Shye, 1994). In the visual representation, humane approaches were closely associated with one-another, as were dominant approaches, confirming the a-priori categories. However, it is worth noting that although there was evidence for discrete categorisation, it is clear that these strategies fall along a continuum, with the most extreme examples of humane and dominant interviewing styles falling at either side of the plot. The boundaries between categories are more blurred towards the centre. This is in line with the 
Police officers' views of

earlier research of Alison et al (2008) in which they found a similar 'coercive-facilitative' continuum.

Insert Figure 1 about here

Insert Table 2 about here

\section{Effects of Discomfort with Ambiguity and Strength of Evidence}

Participants' NFCS scores ranged between 126 and $225(M=167.33, S D=21.44)$. The scores on the discomfort with ambiguity (DA) sub facet ranged from 26 to $49(M=36.10, S D=$ 6.13). Participants were divided into a low-DA group (scores of 36 and lower) and a high-DA group (scores of 37 and higher) using a median split. The average ratings of importance for the 10 dominant and 10 humane interview tactics were calculated for both the soft and the technical evidence conditions. A 2 (Discomfort with ambiguity: high vs. low) $\times 2$ (Evidence: technical vs. soft) $\times 2$ (Tactics: dominant vs. humane) mixed ANOVA with repeated measures on the second and third factors was conducted on the average ratings. The means used in the analysis are displayed in Table 2. Humane tactics were rated as more important $(M=2.95, S D$ $=0.34)$ than dominant tactics $(M=1.66, S D=0.33), F(1,28)=188.40, p<.001, \eta^{2}=.87$. Participants rated more tactics, both dominant and humane, as important if the evidence was soft $(M=2.37, S D=0.24)$ than if it was technical $(M=2.24, S D=0.23), F(1,28)=22.19, p<$ $.001, \eta^{2}=.44$. This supports our first hypothesis, and suggests that interrogators exert more of an effort to increase knowledge in a case with high, as opposed to low, uncertainty.

The main effect of evidence was further qualified by a Discomfort with ambiguity $x$ Evidence interaction, $F(1,28)=8.99, p<.01, \eta^{2}=.24$. Simple-effect analyses revealed that 
Police officers' views of

when there was only soft evidence, high-DA officers $(M=2.47, S D=0.21)$ rated both the humane and dominant tactics as significantly more important than did low-DA officers $(M=$ 2.26, $S D=0.22), F(1,28)=15.05, p<.001$. When the evidence was technical, however, there was no difference between high- and low-DA officers with regard to the rated importance of tactics $(M=2.21, S D=0.20$ vs. $M=2.26, S D=0.27), F(1,28)<1$. This result confirms our second hypothesis, suggesting that participants' discomfort with ambiguity led to increased efforts to gain knowledge in the uncertain case with weak evidence. Also as predicted, discomfort with ambiguity was not associated with differences in preference for tactics in the presence of strong evidence.

\section{Discussion}

In line with previous research (Cherryman \& Bull, 2001; Soukara, Bull \& Vrij, 2002), knowing the case details and the interviewee were considered the most important factors when interviewing a homicide suspect. Also, our participants thought that striving for a confession is important, particularly where the evidence is weak (Moston et al., 1992; McConville \& Hodgson, 1993; Plimmer, 1997; see also Cherryman, 2000). Reasonably, the latter finding is explained by the participants' insight that a confession expedites the legal process (Baldwin, 1993; Evans, 1994; McKenzie, 1994; Milne \& Bull, 1999; Stephenson, 1992), and is of high value for the prosecutor (e.g. Baldwin \& McConville, 1980; Kassin, 1997; Kassin \& Neumann, 1997; McCann, 1998; Stephenson \& Moston, 1994; Underwager \& Wakefield, 1992;

Wakefield \& Underwager, 1998).

The results of this study provide further evidence (see Alison et al, 2008) that there is a meaningful underlying structure to interview tactics and that investigators distinguish tactics from each other according to broad, super-ordinate conceptual categories such as humane vs. dominant. The results also confirmed our first hypothesis, revealing how, in the absence of technical evidence, investigators considered more tactics, both humane and dominant as 
Police officers' views of

important. Thus, the importance of the interview, both for the suspect and interrogator, depends on the weight of the evidence in the case. In conclusion, in addition to having an effect on the suspect's probability of confessing (Evans, 1993; Gudjonsson, \& Bownes, 1992; Gudjonsson \& Petursson, 1991; Holmberg, 2004; Kebbell, Hurren, \& Roberts, 2006; Moston et al, 1992; Viljoen, Klaver, \& Roesch, 2005), the evidence powerfully influences the adopted interview style.

In line with our second hypothesis the present results suggest that an individual's tendency to avoid ambiguity, together with the weight of evidence, relates to his/her perception of effective interview tactics. In the presence of soft evidence, the investigators high (vs. low) in DA had a stronger preference for both humane and dominant tactics. Hence, under these circumstances, investigators high in DA appear to be more likely to try a variety of tactics in order to gain clarity. However, in the presence of technical evidence, and irrespective of DA, all interviewers showed a similar relative preference for the use of humane interview strategies.

The logic behind the demonstrated interaction between the strength of evidence and investigators' discomfort with ambiguity becomes clear when one considers the role of evidence in investigators' construal of a criminal case. Unless there is very strong incriminating evidence against a suspect there will inevitably be some ambiguity as to the suspect's involvement. This assumption finds support in the results of Innes' (2003) field studies of homicide investigations in the UK. Innes reported that police officers mentally reconstructed the crime under investigation in terms of narratives, which were only partly based on hard facts and were completed with inferences about unknown aspects of the case. The regular occurrence of gaps in the police's knowledge means that investigators' ability to handle ambiguity and uncertainty is relevant to the conduct of criminal investigation. The stronger the discomfort that an investigator experiences with ambiguity, the more inclined he/she would be to engage in more controversial strategies to potentially 'plug' the knowledge gaps. Arguably, this tendency 
Police officers' views of

would be stronger the more ambiguity there is regarding the case. In the present study, the manipulation of evidence strength created one case with high ambiguity (i.e., the soft information condition) and one with low ambiguity (i.e., the technical evidence condition). The finding that high-DA investigators were more inclined than low-DA investigators to try a variety of interview tactics when there was high ambiguity probably reflects a more urgent need for knowledge on their part. The absence of such a difference when there was low ambiguity follows naturally from the fact that individuals' orientation towards ambiguity then plays a minor role.

The stronger preference for interview tactics among high-DA investigators in the soft information condition was not limited to humane tactics, which are the most likely to generate diagnostic and reliable information from the suspect. Rather, a similarly significant preference was found for the tactics characterised here as dominant, which may be counterproductive in terms of generating new information. For instance, striving for confrontation is unlikely to be effective in establishing rapport and encouraging the suspect to talk about the crime. In fact, this tactic has been found to produce reluctance among suspects who were willing to cooperate prior to the interview (Gudjonsson, 1995). The indiscriminate effect of evidence strength across both types of tactics is important to bear in mind when drawing implications from the present findings. It appears that increased ambiguity in a case not only makes high-DA investigators put more effort into information-gathering activities, but also increases the risk for less desirable interviewer behaviours. Of course, it remains for future research to establish whether the behavioural inclinations reported in this survey would emerge in actual interviews. In light of previous research in social psychology, however, individual differences in investigators' orientation towards ambiguity can be expected to have real and substantial effects on the social interaction in the interrogation room (Kruglanski et al., 1993; Kruglanski \& Webster, 1991). 
Police officers' views of

Some limitations must be expressed concerning generalising the present results. The current sample was smaller than ideal, and the proportion of females was larger than in the Finnish police population in general. The level of experience varied although all participants had several years of experience on violent crime investigation and interviewing. Future research should control for possible differences in gender and experience. Further, there are several other factors that could not be controlled in the present study, but may influence the interview style, namely, background characteristics of the suspect and the victim (e.g. age, sex, criminal history), characteristics of the crime (e.g. type of crime and severity of violence) and contextual characteristics (presence of a legal advisor, time of day etc). Also, questions may be raised about the extent to which our self-report results adequately capture the dynamics of real police interviews. For example, social desirability may have had an affect on the participants' responses. In order to enhance the reliability of the study the questionnaire was anonymous and the study groups were assured that their anonymity would be protected. Future research should however be conducted by analysing audio-taped interviews in real or high-fidelity simulated criminal cases with different weights of evidence. For example, by observing police interviews in the field Gozna, Sully and Teicher (2005) showed that suspects use different counterinterrogation tactics in the interview depending on the suspect's evaluation of the situation and the likely disposal decision. Similarly, Pearse and Gudjonsson (1999) showed that the emphasis of different interview tactics fluctuate across an interview.

The implications of this study, although being based on a small sample, are clear. The demonstrated interactive effect between the strength of evidence and investigators' discomfort with ambiguity on the importance of different interview tactics raises several important questions for senior investigative officers assigning interviewers to particular cases. For future research, the need for studying police interviewing with an applied setting in mind is significant. 
Police officers' views of

\section{References}

Alison, L, Kebbell, M. \& Leung, J. (2008). A facet analysis of police officers' selfreported use of suspect-interviewing strategies and their Discomfort with Ambiguity Applied Cognitive Psychology.

Anseel, F., \& Lievens, F. (2007). The relationship between uncertainty and desire for feedback: A test of competing hypotheses. Journal of Applied Social Psychology 37, 1007-1040.

Asch, S. E. (1956). Studies of independence and conformity: A minority of one against a unanimous majority. Psychological Monographs 70, 416.

Ask, K., \& Granhag, P. A. (2005). Motivational sources of confirmation bias in criminal investigations: The need for cognitive closure. Journal of Investigative Psychology and Offender Profiling, 2, 43-63.

Ask, K., \& Granhag, P. A. (2007). Motivational bias in criminal investigators judgments of witness reliability. Journal of Applied Social Psychology, 37, 561-591.

Ask, K., Rebelius, A., \& Granhag, P. A. (2008). The "elasticity” of criminal evidence: A moderator of investigator bias. Applied Cognitive Psychology, 22.

Baldwin, J. (1992). Video Taping Police Interviwes with Suspects - An Evaluation. Police Research group. Police Research series Paper 1. London: Home Office.

Baldwin, J. (1993). Police interview techniques: Establishing truth or proof?. British Journal of Criminology 33, 325-352.

Baldwin, J. \& McConville, M. (1980). Confessions in Crown Court trials. Royal Commission of Criminal Procedure. Research Study No. 5. London: HMSO.

Bull, R. (1999). Police investigative interviewing. In Memon A. \& Bull, R. (eds) Handbook of the psychology of interviewing. Wiley, Chichester.

Cherryman, J. (2000). Police investigative interviewing: Skill analysis and concordance of evaluations. Unpublished Ph.D. thesis, University of Portsmouth. 
Police officers' views of

Cherryman, J. \& Bull, R. (2000). Investigative interviewing. In Leishman, F., Loveday, B. \& Savage, S. P. (eds) Core issues in policing $\left(2^{\text {nd }}\right.$ ed), Longman, London.

Cherryman, J. \& Bull, R. (2001). Police officers perception of specialist investigative interviewing skills. International Journal of Police Science and Management 3, 199-212.

Eronen, M., Hakola, P. and Tiihonen, J. (1996) ‘Mental Disorders and Homicidal Behaviour in Finland'. Archives of General Psychiatry 53, 497-501.

Evans, R. (1993). The conduct of police interviews with juveniles (Royal Commission on Criminal Justice Report). London: HMSO.

Evans, R. (1994). Police interviews with juveniles. In D. Morgan \& G. M. Stephenson (eds.) Suspicion and silence: The right to silence in criminal investigations (pp. 77-90). London: Blackstone.

Firth, A. (1975). Interrogation. Police Review 4324,1507.

Gozna, L. F., Sully, L., \& Teicher, S. (2005). It weren't me Gov, honest! Observations of the suspect tactics in real life police interviews. Paper presented at the 8th International Investigative Psychology Conference, London, UK.

Greenwood, P. W., Chaiken, J. M., \& Petersilia, J. (1977). The criminal investigation process. Lexington, MA: Heath.

Gudjonsson, G. H. (1995). The effects of interrogative pressure on strategic coping. Psychology, Crime \& Law, 1, 309-318.

Gudjonsson, G. H. (2003). The psychology of interrogations and confessions: A handbook. New York: Wiley.

Gudjonsson, G. H., \& Bownes, I. (1992). The reason why suspects confess during custodial interrogation: data from Northern Ireland. Medicine, Science and the Law, 32, 204-212. 
Police officers' views of

Gudjonsson, G. H., \& Petrusson, H. (1991). Custodial interrogation: why do suspects confess and how does it relate to their crime, attitude and personality. Personality and Individual Differences 12, 295-306.

Gudjonsson, G. H. (1993). Confession Evidence, Psychological Vulnerability and Expert Testimony. Journal of Community and Applied Social Psychology, 3, 117-129.

Hargie, O. \& Tourish, D. (1999). The psychology of interpersonal skill. In A. Memon \& R. Bull (eds), Handbook of the Psychology of Interviewing (pp. 71-87). Chichester: Wiley.

Hartwig, M., Granhag P. A., \& Vrij, A. (2005). Police interrogation from a social psychology perspective. Policing \& Society 15(4), 379-399.

Holmberg, U. (2004). Police interview with victims and suspects of violent and sexual crimes; interviewees' experiences and interview outcomes. Unpublished $\mathrm{PhD}$ thesis, Stockholm University.

Holmberg, U. \& Christianson, S-Å. (2002). Murderers' and Sexual Offernders' Experiences of Police Interview and Their Inclination to Admit or Deny Crime. Behavioural Sciences and the Law, 20, 1-14.

Huff, C.R., Rattner, A. \& Sagarin, E. (1996). Convicted but Innocent: Wrongful Conviction and Public Policy. Sage, Thousand Oaks, CA.

Innes, M. (2003). Investigating murder: Detective work and the police response to criminal homicide. Oxford, England: Oxford University Press.

Jones, T., Maclean, B., \& Young, J. (1986). The Islington Crime Survey, Crime Victimization and Policing in Inner City London, Gower, London.

Kassin, S. M. (1997). The psychology of confession evidence. American Psychologist 52, 221233.

Kassin, S. M. \& Neumann, K. (1997). On the power of confession evidence: An experimental test of the fundamental difference hypothesis. Law and Human Behavior 21, 469-484. 
Police officers' views of

Kebbell, M. R., Hurren, E. J., \& Roberts, S. (2006). Mock-suspects' decision to confess: the accuracy of eyewitness evidence is critical. Applied Cognitive Psychology 20, 477-486.

Kosic, A., Kruglanski, A. W., Pierro, A., \& Mannetti, L. (2004). The social cognition of immigrants' acculturation: Effects of the need for closure and the reference group at entry. Journal of Personality and Social Psychology, 86, 796-813.

Kruglanski, A. W. (1989). Lay epistemics and human knowledge: Cognitive and motivational bases. New York: Plenum Press.

Kruglanski, A. W. (1996). Motivated social cognition: Principles of the interface. In E. T. Higgins (Ed.), Social psychology: Handbook of basic principles (pp. 493-520). New York: Guilford Press.

Kruglanski, A. W., \& Freund, T. (1983). The freezing and unfreezing of lay-inferences: Effects on impressional primacy, ethnic stereotyping, and numerical anchoring. Journal of Experimental Social Psychology, 19, 448-468.

Kruglanski, A. W., \& Webster, D. M. (1991). Group members' reactions to opinion deviates and conformists at varying degrees of proximity to decision deadline and of environmental noise. Journal of Personality and Social Psychology, 61, 212-225.

Kruglanski, A. W., \& Webster, D. M. (1996). Motivated closing of the mind: "Seizing" and "freezing." Psychological Review, 103, 263-283.

Kruglanski, A. W., Webster, D. M., \& Klem, A. (1993). Motivated resistance and openness to persuasion in the presence or absence of prior information. Journal of Personality and Social Psychology, 65, 861-876.

Kunda, Z. (1990). The case for motivated reasoning. Psychological Bulletin, 108, 480-498.

Leo, R. A. (1992). From coercion to deception: The changing nature of police interrogation in America. Crime, Law, and Social Change 18, 33-59. 
Police officers' views of

Leo, R. A. (1996). Inside the interrogation room. Journal of Criminal Law and Criminology 86, 266-303.

Mayseless, O., \& Kruglanski, A. W. (1987). What makes you so sure? Effects of epistemic motivations on judgmental confidence. Organizational Behavior and Human Decision Processes, 39, 162-183.

Mccann, J. T. (1998). A conceptual framework for identifying various types of confessions. Behavioural Sciences and the Law 16, 441-453.

McConville, M. \& Hodgson, J. (1993). Custodial legal advice and the right to silence. Royal Commission on Criminal Justice Research, Research Study no 16. London: HMSO.

McKenzie, I. K. (1994). Regulating custodial interviews: A comparative study. International Journal of the Sociology of Law 22, 239-259.

Memon, A., Vrij, A., \& Bull, R. (2003). Psychology and the Law: Truthfulness, Accuracy and Credibility, 2nd edn, Wiley, Chichester.

Milne, B., \& Bull, R. (1999). Investigative interviewing: Psychology and Practice. Wiley, Chichester.

Mortimer, A. (1994). Asking the right questions. Policing 10, 111-24.

Mortimer, A. \& Shepherd, E. (1999). Frames of mind: Schemata guiding cognition and conduct in the interviewing of suspected offenders. In A. Memon \& R. Bull (eds), Handbook of the Psychology of Interviewing (pp. 293-315). Chichester: Wiley.

Moston, S. (1996). From denial to admission in police questioning of suspects. In G. Davies, S. Lloyed-Bostock, M. McMurran \& C. Wilson (eds), Psychology, law and criminal justice: international developments in research and practice (pp. 91-99). Berlin: de Gruyter.

Moston, S., \& Engelberg, T. (1993). Police questioning techniques in tape-recorder interviews with criminal suspects. Policing and Society 6, 61-75. 
Police officers' views of

Moston, S., \& Stephenson, G. (1993). The changing face of police interrogation. Journal of Community and Social Psychology 3, 101-115.

Moston, S., Stephenson, GM \& Williamson, TM. (1992). The effects of case characteristics on suspect behaviour during police questioning. British Journal of Criminology 32, 23-40.

Moston, S., Stephenson, G. M- \& Williamson, T. M. (1993). The incidence, antecedents and consequences of the use of right to silence during police questioning. Criminal Behaviour and Mental Health 3, 30-47.

Neuberg, S. L., Judice, T. N. \& West, S. G. (1997). What the Need for Closure Scale measures and what it does not: Toward differentiating among related epistemic motives. Journal of Personality and Social Psychology 72, 1396-1412.

Nicol, C., Innes, M., Gee, D, \& Feist, A. (2004). Reviewing murder investigations: An analysis of progress reviews from six police forces (Home Office Online Report 25/04). London: Home Office.

Pearse, J., \& Gudjonsson, G. H. (1996). Police interviewing techniques at two south London police stations. Psychology, Crime and Law 3, 63-74.

Pearse, J., \& Gudjonsson, G. H. (1999). Measuring influential police interviewing tactics: A factor analytic approach. Legal and Criminological Psychology 4(2), 221-238.

Plimmer, J. (1997). Confession rate. Police Review 7, February 16-18.

Shye, S., Elizur, D., \& Hoffman, M. (1994). Introduction to Facet Theory: Content Design and Intrinsic Data Analysis in Behavioural Research. London: Sage Publications.

Smith, D. J. (1983). Police and people in London, (I), A Survey of Londoners, Policy Studies Institute, London.

Soukara, S., Bull, R., \& Vrij, A. (2002). Police detectives' aims regarding their interviews with suspects: Any change at the turn of the millennium? International Journal of Police Science and Management 4, 101-114. 
Police officers' views of

Stephenson, G. M. (1992). The psychology of criminal justice. Oxford: Blackwell.

Stephenson, G. M. \& Moston, S. (1994). Police interrogation. Psychology, Crime and Law 1, 151-157.

Underwager, R. \& Wagefield, H. (1992). False confessions and police deception. American Journal of Forensic Psychology 10, 49-66.

Viljoen, J. L., Klaver, J., \& Roesch, R. (2005). Legal decision of preadolescent and adolescent defendants: predictors of confessions, pleas, communication with attorneys, and appeals. Law and Human Behavior, 29, 253-277.

Vrij, A. (2003). "We will protect your wife and child, but only if you confess": Police interrogations in England and the Netherlands. In P. J. van Koppen \& S. D. Penrod (eds), Adversarial versus inquisitorial justice: Psychological perspectives on criminal justice system (pp. 57-79). New York: Plenum.

Wagefield, H. \& Underwager, R. (1998). Coerced or nonvoluntary confessions. Behavioral Sciences and the Law 16, 423-440.

Webster, D. M. (1993). Motivated augmentation and reduction of the overattribution bias. Journal of Personality and Social Psychology, 65, 261-271.

Webster, D. M., \& Kruglanski, A. W. (1994). Individual differences in need for cognitive closure. Journal of Personality and Social Psychology, 67, 1049-1062.

Webster, D. M., Richter, L., \& Kruglanski, A. W. (1996). On leaping to conclusions when feeling tired: Mental fatigue effects on impressional primacy. Journal of Experimental Social Psychology, 32, 181-195.

Webster Nelson, D., Klein, C. T. F., \& Irvin, J. E. (2003). Motivational antecedents of empathy: Inhibiting effects of fatigue. Basic and Applied Social Psychology, 25, 37-50.

Williamson, T. M. (1993). From interrogation to investigative interviewing: strategic trends in police questioning. Journal of Community and Social Psychology 3, 89-99. 
Police officers' views of

\section{Acknowledgements}

Grateful acknowledgement is given to the violent crime investigators for their co-operation in this study. We would also like to thank Mrs Heli Roppola for translating the NFC scale into Finnish. The first author would like to thank the Academy of Finland (personal Grants no 75697 and no 211176) for financial support. 
Police officers' views of

Table 1. Means, standard deviations and \% of participants considering the tactics "very important" in technical and soft conditions.

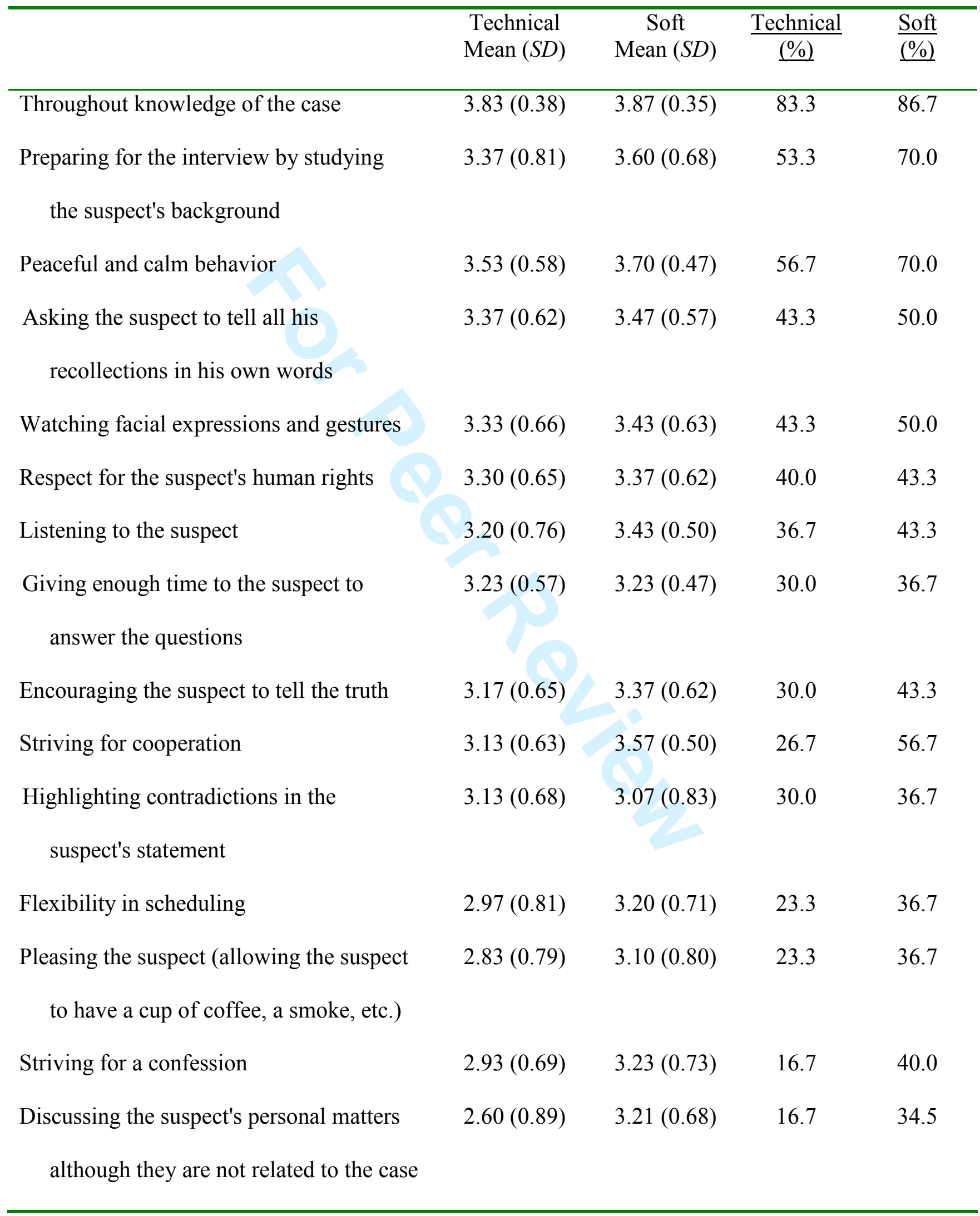




\begin{tabular}{|c|c|c|c|c|}
\hline Convincing the suspect that denying the & $2.70(0.70)$ & $3.03(0.56)$ & 13.3 & 16.7 \\
\hline \multicolumn{5}{|l|}{ offence does not serve his/her interests } \\
\hline Candour, lack of presumptions & $2.87(0.68)$ & $2.90(0.66)$ & 13.3 & 16.7 \\
\hline Considerate and helpful behavior & $2.60(0.62)$ & $2.77(0.68)$ & 6.7 & 13.3 \\
\hline Repeating the question if the answer is not & $2.57(0.82)$ & $2.53(0.82)$ & 10.0 & 10.0 \\
\hline \multicolumn{5}{|l|}{ what you expected } \\
\hline Humor & $2.47(0.78)$ & $2.57(0.73)$ & 13.3 & 13.3 \\
\hline Compassionate and sensitive attitude & $2.47(0.82)$ & $2.53(0.68)$ & 6.7 & 6.7 \\
\hline Having a friendly attitude & $2.10(0.71)$ & $2.30(0.60)$ & 3.3 & 3.3 \\
\hline Striving for finding out the truth as soon as & $2.07(0.87)$ & $2.03(0.93)$ & 6.7 & 3.3 \\
\hline \multicolumn{5}{|l|}{ possible } \\
\hline Making the suspect insecure & $1.90(0.71)$ & $2.20(0.85)$ & & 3.3 \\
\hline Keeping a long silence after the suspect & $1.83(1.02)$ & $1.93(0.98)$ & 10.0 & 6.7 \\
\hline \multicolumn{5}{|l|}{ has answered an important question } \\
\hline Formal behaviour & $1.83(0.70)$ & $1.83(0.71)$ & 3.3 & 3.3 \\
\hline Striving for using similar language (e.g. & $1.83(0.83)$ & $1.83(0.91)$ & 3.3 & 6.7 \\
\hline \multicolumn{5}{|l|}{ slang) } \\
\hline Persistence and stubbornness & $1.67(0.76)$ & $1.77(0.68)$ & 3.3 & - \\
\hline Striving for confrontation & $1.47(0.78)$ & $1.67(0.80)$ & 3.3 & 3.3 \\
\hline Disclosing information about yourself (e.g. & $1.43(0.57)$ & $1.60(0.89)$ & & 6.7 \\
\hline \multicolumn{5}{|l|}{ "I have been in this job for XX years). } \\
\hline Wearing the same kind of clothing as the & $1.50(0.78)$ & $1.40(0.68)$ & & \\
\hline \multicolumn{5}{|l|}{ suspect (appearance) } \\
\hline Ingratiating yourself with the suspect & $1.20(0.41)$ & $1.53(0.57)$ & & \\
\hline Hostile attitude & $1.07(0.25)$ & $1.10(0.31)$ & & \\
\hline
\end{tabular}


Police officers' views of

\begin{tabular}{lll}
\hline Disregarding and insensitive attitude & $1.20(0.41)$ & $1.13(0.35)$ \\
Shifting the blame partly to the victim & $1.13(0.35)$ & $1.20(0.41)$ \\
Downplaying the seriousness of the & $1.10(0.31)$ & $1.13(0.35)$ \\
$\quad$ & & \\
offence & $1.07(0.25)$ & $1.13(0.35)$ \\
Making the suspect angry & $1.10(0.31)$ & $1.03(0.18)$ \\
Judgmental attitude & & \\
\end{tabular}


Police officers' views of

Table 2. Abbreviation of Figure 1 and their definitions.

\begin{tabular}{|c|c|}
\hline Abbreviation & Definition \\
\hline Insecure & Making the suspect insecure \\
\hline Angry & Making the suspect angry \\
\hline Disregard & Disregarding and insensitive attitude \\
\hline Silence & Keeping a long silence after the suspect has answered an important question \\
\hline Hostile & Hostile attitude \\
\hline Confess & Striving for a confession \\
\hline Stubborn & Persistence and stubbornness \\
\hline Confront & Striving for confrontation \\
\hline Judge & Judgemental attitude \\
\hline Formal & Formal behaviour \\
\hline Favour & Pleasing the suspect (allowing the suspect to have a smoke etc.) \\
\hline Peace & Peaceful and calm behaviour \\
\hline Help & Considerate and helpful behaviour \\
\hline Humour & Humour \\
\hline Friendly & Having a friendly attitude \\
\hline Sensitive & Compassionate and sensitive attitude \\
\hline Respect & Respect for the suspect's human rights \\
\hline Cooperation & Striving for cooperation \\
\hline Candour & Candour, lack of presumptions \\
\hline Recollect & Asking the suspect to tell all his recollections in his own words \\
\hline
\end{tabular}


Police officers' views of

Table 3. Mean and standard deviations of average reported use of tactics for officers high and low in DA, humane/dominant tactics, and soft/technical evidence (standard deviations in brackets).

\begin{tabular}{lcc}
\hline & \multicolumn{2}{c}{ Discomfort with ambiguity } \\
\hline Tactic & $(N=15)$ & High \\
& & $(N=15)$ \\
Humane & $2.93(0.26)$ & $3.12(0.41)$ \\
Soft & $2.87(0.25)$ & $2.87(0.48)$ \\
Technical & & \\
& & \\
Dominant & $1.59(0.25)$ & $1.82(0.39)$ \\
Soft & $1.56(0.29)$ & $1.65(0.41)$ \\
Technical & & \\
\hline
\end{tabular}


Police officers' views of

Figure 1. The visual representation of the correlations between the tactics. Mean of both condition, $\mathrm{CoA}=0.14341$ 


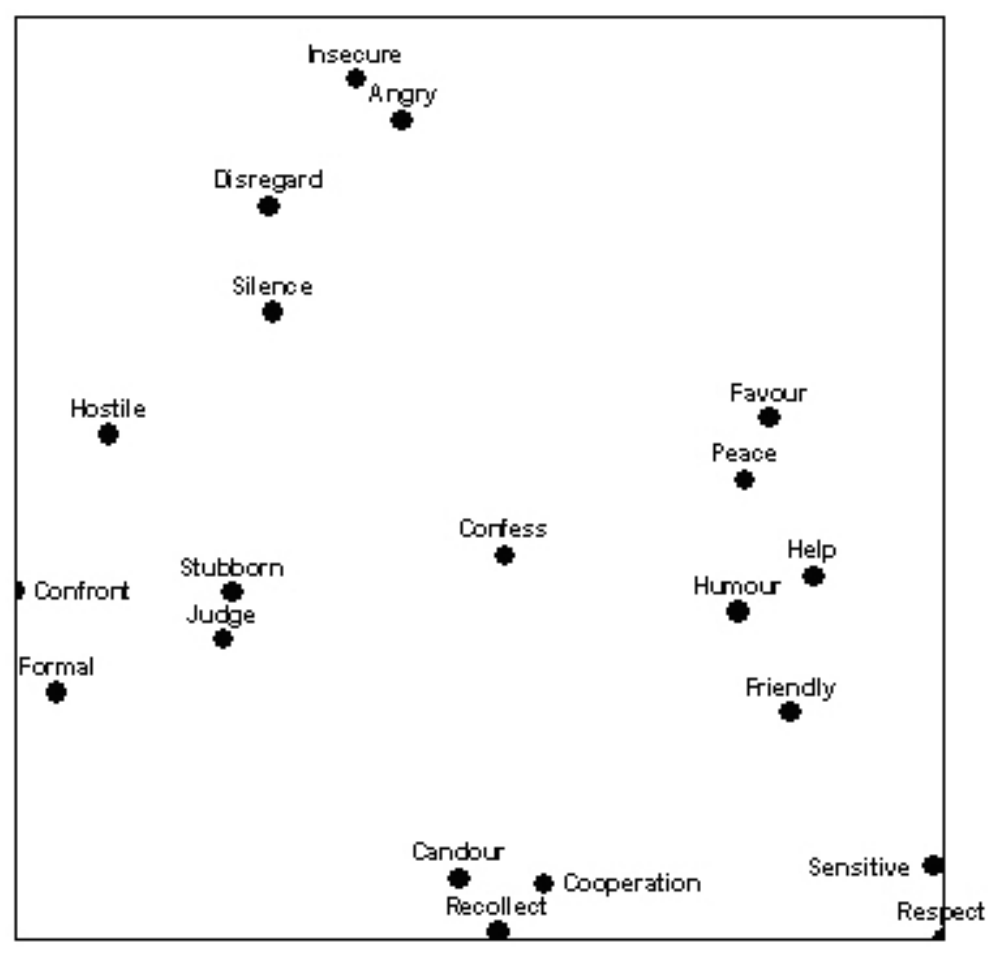

$105 \times 98 \mathrm{~mm}(96 \times 96 \mathrm{DPI})$ 